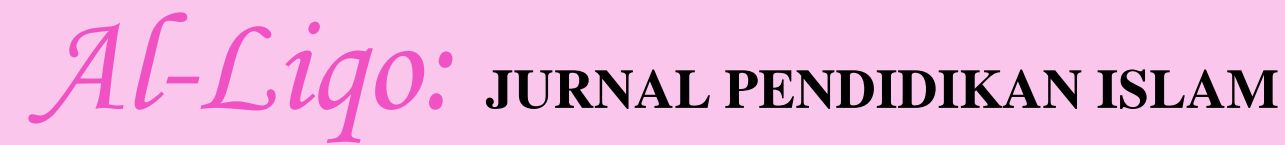 \\ P-ISSN: 2461-033X | E-ISSN: 2715-4556
}

\section{PENGEMBANGAN KREATIVITAS GURU DALAM PROSES PEMBELAJARAN}

\author{
*Humaidi Humaidi ${ }^{1)}$ Moh. Sain ${ }^{2)}$ \\ ${ }^{1)}$ STAI Syaichona Moh. Cholil Bangkalan, Propinsi Jawa Timur. (tafakkursaatan@gmail.com) \\ ${ }^{2}$ STAI Auliaurrasyidin Tembilahan, Indragiri Hilir, Riau. (moh.sain@stai-tbh.ac.id)
}

\begin{abstract}
Creativity is a key oriented towards the effectiveness of the learning process carried out by the teacher in achieving learning and educational goals. This study aims to reveal the teachers' creativity in the learning process. Teacher's creativity is the skills to have such as skills in making teaching materials, carrying out learning in class properly, learning methods that are relevant to the material, appropriate learning media, quality learning resources related to the discussion, etc. The research method used was a qualitative descriptive approach, and the research subjects are teachers in schools who expected to have creativity in the form of quality skills.
\end{abstract}

Keywords: Teacher's creativity, Learning process, Skills

\begin{abstract}
Abstrak
Kreativitas menjadi kunci yang berorientasi kepada efektifnya proses pembelajaran yang dilakukan oleh guru dan pencapaian tujuan pembelajaran dan pendidikan yang optimal. Penelitian ini bertujuan untuk mengungkap kreativitas guru dalam proses pembelajaran. Kreativitas guru dimaksud adalah keterampilan yang harus dimiliki guru seperti keterampilan dalam membuat bahan ajar, melaksanakan pembelajaran di kelas dengan baik, metode pembelajaran yang relevan dengan materi yang disampaikan, media pembelajaran yang tepat untuk digunakan, sumber belajar yang berkualitas yang berkaitan dengan pembahasan dan masih banyak lagi kreativitas-kreativitas lain yang harus dilakukan guru di sekolah. Metode penelitian yang digunakan penulis bersifat kualitatif dengan pendekatan deskriptif kualitatif. Dan subjek penelitian adalah guru di sekolah yang diharapkan memiliki kreativitas berupa keterampilan yang bermutu.
\end{abstract}

Kata Kunci: Kreativitas Guru, Proses Pembelajaran, Keterampilan

\section{Cara Mensitasi Artikel:}

Humaidi, H., \& Sain, M. (2020). Pengembangan kreativitas guru dalam proses pembelajaran. AlLiqo: Jurnal Pendidikan Islam, 5(02), 146-160. https://doi.org/10.46963/alliqo.v5i02.238

\begin{tabular}{|c|c|}
\hline $\begin{array}{l}\text { *Corresponding author: } \\
\text { tafakkursaatan@gmail.com }\end{array}$ & $\begin{array}{ll} & \text { Histori Artikel: } \\
\text { Diterima } & : 30 / 11 / 2020 \\
\text { Direvisi } & :- \\
\text { Diterbitkan }: 28 / 12 / 2020\end{array}$ \\
\hline DOI: https: & alliqo.v5i02.238 \\
\hline
\end{tabular}




\section{PENDAHULUAN}

Kreativitas merupakan sebuah permasalahan yang menarik dan memiliki cakupan yang sangat luas. Kreativitas merupakan suatu kondisi, sikap atau keadaan yang sangat khusus sifatnya dan hampir tidak mungkin dirumuskan secara tuntas. Kreativitas dapat diartikan dengan beraneka ragam pernyataan, tergantung siapa dan bagaimana menyorotinya. Kreativitas merupakan hal yang sangat penting, baik untuk konteks individu maupun lingkungan sosial. Dalam konteks individu, kreativitas relevan dengan kebutuhan seseorang dalam menyelesaikan masalah pekerjaan atau masalah dalam kehidupan sehari-hari.

Kreativitas peserta didik dalam proses pembelajaran sangat bergantung pada kreativitas guru dalam mengembangkan materi standar, dan menciptakan lingkungan belajar yang kondusif. (Ahmad Syaikhudin, 2013: 318). Menurut Marno (2011:7) bahan ajar merupakan bahan atau materi pembelajaran yang disusun secara sistematis yang digunakan guru dan siswa dalam proses pembelajaran. Selanjutnya, secara umum Ali Mudlofir (2011:127) menjelaskan bahwa bahan ajar adalah segala bentuk bahan yang digunakan untuk membantu guru/instruktur dalam melaksanakan kegiatan belajar mengajar. Bahan yang dimaksud bisa berupa bahan tertulis maupun bahan tidak tertulis.

Guru perlu mengembangkan kreativitasnya sebagai upaya pembaharuan proses pembelajaran di sekolah, seorang guru diharuskan mempunyai pandangan atau pendapat yang positif terhadap bagaimana menciptakan situasi dan kondisi belajar yang diharapkan, karena secara operasional gurulah yang terlibat langsung dalam proses pembelajaran di sekolah. (Monawati, 2018: 33)

\section{METODE}

Penelitian ini menggunakan jenis penelitian kualitatif. Penelitian kualitatif yang dimaksud adalah memahami teori-teori tentang apa yang dialami oleh subjek penelitian yakni guru di sekolah. Pendekatan kualitatif yang digunakan adalah pendekatan deskriptif kualitatif, sebab masalah yang penulis teliti memerlukan suatu penjelasan lebih lanjut yang bersifat deskriptif dan komprehensif. Pemilihan pendekatan ini didasarkan atas pertimbangan bahwa data yang hendak dicari 
adalah data yang menggambarkan kreativitas guru dalam proses pembelajaran. Data yang dicari akan lebih tepat diungkapkan dalam bentuk kata-kata. Prosedur penelitian kualitatif tidak terbatas hanya pada teknik pengumpulan dan penyusunan data saja untuk dikumpulkan, tetapi sampai kepada analisis data secara induktif, deduktif, dan komprehensif dan interpretasi tentang arti apa yang diteliti.

1. Sumber Data

Kajian yang penulis gunakan adalah penelitian perpustakaan murni, penulis akan menggunakan dua sumber, yaitu:

a. Sumber Primer

Sumber data yang berifat primer adalah buku rujukan awal dan utama dalam penelitian, sumber primer yang penulis gunakan adalah :

1) Jufni, M., Djailani, A. R., \& Ibrahim, S. (2015). Kreativitas Guru Pai Dalam Pengembangan Bahan Ajar Di Madrasah Aliyah Jeumala Amal Lueng Putu. Jurnal Administrasi Pendidikan: Program Pascasarjana Unsyiah, Volume 3, Nomor. 4, November.

2) Monawati, M., \& Fauzi, F. (2018). Hubungan Kreativitas Mengajar Guru dengan Prestasi Belajar Siswa. Jurnal Pesona Dasar, Volume 6 Nomor 2 Oktober.

3) Syaikhudin, Ahmad. (2013). Pengembangan Kreativitas Guru Dalam Proses Pembelajaran. LISAN AL-HAL: Jurnal Pengembangan Pemikiran dan Kebudayaan, Volume 7, Nomor. 2.

b. Sumber Sekunder

Sumber sekunder adalah hasil pengumpulan yang dilakukan oleh orang lain dengan maksud tertentu dan mempunyai kategori atau klasifikasi menurut keperluan masing-masing dan kegunaan bagi peneliti masingmasing, S. Nasotion ( 2002: 143)

Dalam hal ini Sumber data yang bersifat sekunder adalah buku rujukan pendukung dalam penelitian, sumber sekunder yang penulis gunakan adalah: 
1) Mamo, (2011). Pengembangan Bahan Ajar PAI Pada Sekolah. Direktorat Pendidikan Agama Islam Kementerian Agama Republik Indonesia.

2) Miranda, D. (2016). Upaya Guru Dalam Mengembangkan Kreativitas Anak Usia Dini di Kota Pontianak. Jurnal Pembelajaran Prospektif, Volume 1 Nomor 1.

3) Monawati, M., \& Fauzi, F. (2018). Hubungan Kreativitas Mengajar Guru dengan Prestasi Belajar Siswa. Jurnal Pesona Dasar, Volume 6 Nomor 2 Oktober.

4) Ali. Mudlofir. (2011). Aplikasi Pengembangan Kurikulum Tingkat Satuan Pendidikan (KTSP) dan Bahan Ajar dalam Pendidikan Agama Islam. Jakarta: Rajawali Pers.

5) Luqita, Aria. Agus Susanti. (2013). Perspektif Guru Terhadap Kemitraan Antara Sekolah, Guru Dan Masyarakat. Jurnal Psikologi Industri dan Organisasi Volume 2 Nomor. 2, Agustus.

6) Hamzah B. Uno dan Nurdin Mohamad, (2012). Belajar dengan Pendekatan PAIKEM, Jakarta: Bumi Aksara.

2. Teknik Pengumpulan Data

Teknik pengumpulan data adalah cara-cara yang digunakan oleh peneliti untuk mengumpulkan data. Pengumpulan data dalam penelitian ini adalah dengan cara dokumentasi. Dokumentasi adalah "ditujukan untuk memperoleh data langsung dari tempat penelitian, meliputi buku-buku yang relevan, peraturan-peraturan, laporan kegiatan, foto-foto, fim, dokumenter, data yang relevan penelitian, Riduwan (2013: 24).

3. Teknik Analisa Data

Teknik analisa data adalah cara penghitungan untuk menjawab rumusan masalah dan pengujian hipotesis yang diajukan, Riduan ( 2015: 12). Hipotesis adalah jawaban sementara yang harus di uji kebenarannya. Namun, penelitian yang penulis gunakan dengan kajian pustaka (library research) ini, maka penulis menggunakan teknik analisa data kajian isi (countent analysis). 
Kajian ini adalah kajian yang memanfaatkan buku atau dokumen untuk menarik kesimpulan, baik kajian isi yang bersifat deduktif maupun kajian isi yang bersifat induktif, Lexy J. Moleong (2013: 220). Pada kajian ini peneliti terlebih dahulu mengadakan survei data untuk memperoleh informasi dari penelitian terdahulu terhadap pengerjaan tanpa memedulikan apakah data itu primer atau sekunder, di lapangan atau di laboratorium. Kemudian, menelusuri literatur yang ada serta menelaahnya secara tekun. Setelah itu, peneliti mengungkapkan buah pikiran secara kritis dan analitis, Moh. Nazir (2005: 93).

\section{HASIL DAN PEMBAHASAN}

\section{Kreativitas}

Kreativitas berasal dari kata dasar kreatif (creative), berarti menggunakan hasil ciptaan atau kreasi baru atau yang berbeda dengan sebelumnya. (Muhammad Jauhar, 2011: 162). Kreasi merupakan ciptaan buah pikiran atau kecerdasan akal manusia. Kreasi adalah proses terjadinya kegiatan yang bertujuan menghasilkan suatu benda dari yang tidak ada menjadi ada. Kreatif adalah menciptakan sesuatu yang berbeda dari yang lain. Kreativitas adalah ciri khas seseorang untuk menghasilkan ide-ide baru, alternatif, solusi, dan kemungkinan dengan cara unik dan berbeda.

Menurut Yatim Rianto, kreativitas adalah suatu proses yang menuntut keseimbangan dan aplikasi dari ketiga aspek esensial kecerdasan analitis, kreatif dan praktis, beberapa aspek yang ketika digunakan secara kombinatif dan seimbang akan melahirkan kecerdasan kesuksesan. (Yatim Rianto, 2010: 225).

Kecerdasan analitis adalah kemampuan yang diperlukan untuk mempertimbangkan nilai dari gagasan seseorang dan untuk memutuskan mana diantara gagasan tersebut yang layak diwujudkan. Kemampuan analitis selanjutnya dapat digunakan untuk mengevaluasi keunggulan dan kelemahan dari gagasan itu dan menunjukkan cara-cara dalam menyempurnakan gagasan. Orang dengan daya sintesa tinggi namun rendah daya analisisnya barangkali 
akan membutuhkan orang lain untuk mengisi peran penilaian ini, bila tidak maka gagasan yang hendak diwujudkan kurang berharga. Pembelajaran yang kreatif mengandung makna tidak sekedar melaksanakan dan menerapkan kurikulum. Kurikulum memang merupakan dokumen dan rencana baku, namun tetap perlu dikritisi dan dikembangkan secara kreatif. Dengan demikian, ada kreativitas pengembangan kompetensi dan kreativitas dalam pelaksanaan pembelajaran di kelas termasuk pemanfaatan lingkungan sebagai sumber bahan dan sarana untuk belajar yang beragam sehingga memenuhi berbagai tingkat kemampuan siswa dan tipe serta gaya belajar siswa. (Muhammad Jauhar, 2011 : 162).

Kreativitas adalah salah satu kata kunci yang perlu dilakukan guru untuk memberikan layanan pendidikan yang maksimal sesuai kemampuan dan keahlian khusus dalam bidang keguruan. (Hamzah B. Uno dan Nurdin Mohamad, 2012: 153). Sebagai pemberi layanan pendidikan melalui kegiatan mengajar, guru melakukan aktivitasnya dalam konteks pendidikan yang berperan sebagai fasilitator, mediator, dan evaluator.

Peran guru sebagai fasilitator, berkreativitas secara bersama pada individu ataupun sosial yang berkonsekuensi terjadinya perubahan pola hubungan antara siswa dan guru dalam bentuk kemitraan. Guru harus mengetahui perannya sebagai fasilitator dengan baik karena dalam proses kegiatan belajar mengajar di sekolah terutama di dalam kelas harus memberikan kemudahan atau fasilitas kepada siswa agar saat proses belajar siswa lebih mudah memahami dan mengerti mengenai materi yang disampaikan. Guru berperan sebagai mediator adalah guru dapat menjadi penengah dan pengatur jalannya pembelajaran pada saat siswa melakukan masalah. Guru berperan sebagai evaluator yaitu guru mampu menilai secara produk (hasil pengajaran) dan proses (jalannya pengajaran). (Rahmawati Pamungkas dkk, 2017: 5-6).

Kemitraan yang dimaksud merupakan sesuatu yang utuh karena masing-masing pihak akan saling bertukar pikiran, berbagi ide, pendapat, dan hal-hal yang dapat membangun perubahan diri ke arah yang lebih baik. Fungsi 
pelayanan sangat jelas, karena guru merupakan orang dekat "sahabat" bagi siswa. Sahabat adalah orang yang sangat dekat dan selalu ada ketika merasakan suka maupun duka secara bersama-sama walaupun sebenarnya ada jarak yang berbeda antara guru dan siswa.

Kemitraan dengan keluarga dan dukungan sosial dari lingkungan masyarakat juga merupakan salah satu faktor yang sagat penting bagi keberhasilan program inklusif. Kemitraan ini akan memberikan kontribusi pada pengembangan kompetensi pengasuhan yang efektif, maupun kompetensi pribadi dan intelektual pada siswa. Keluarga dan kebutuhan siswa, serta keragaman sosial dan budaya perlu untuk diperhitungkan untuk pemahaman yang lebih besar ketika mengembangkan kemitraan. (Aria Luqita dkk, 2013: 161).

Kreativitas guru adalah kemampuan seseorang untuk melahirkan sesuatu yang baru maupun mengembangkan hal-hal yang sudah ada untuk memberikan sejumlah pengetahuan kepada siswa di sekolah. Peneliti merincikan kreativitas sebagai berikut:

a. Kreatif sering digambarkan dengan kemampuan berpikir kritis dan banyak ide, serta banyak ide dan gagasan.

b. Orang kreatif melihat hal yang sama, tetapi melalui cara berpikir yang beda.

c. Kemampuan menggabungkan sesuatu yang belum pernah tergabung sebelumnya.

d. Kemampuan untuk menemukan atau mendapatkan ide dan pemecahan baru.

\section{Kreativitas Dalam Mengajar.}

Keberadaan guru memiliki peranan yang sangat penting dalam mencerdaskan anak bangsa, sehingga diharapkan guru harus memenuhi persyaratan menjadi guru yang profesional. Undang-Undang Nomor 14 Tahun 2005 mengatur tentang Guru dan Dosen pasal 1 ayat 1 menyatakan bahwa guru adalah pendidik yang profesional memiliki tugas utama sebagai dalam mendidik, mengajar, membimbing, mengarahkan, melatih, dan mengevaluasi 
siswa pada jenjang pendidikan anak usia dini, jenjang pendidikan dasar, dan jenjang menengah.

Pentingnya kreativitas dapat dibuktikan melalui salah satu tokoh dunia bernama Thomas alva edison yang terkenal sebagai penemu bola lampu pijar yang hingga saat ini kita nikmati manfaatnya yang merupakan buah dari kreativitas. Namun itu bukan satu-satunya temuan yang dimiliki oleh sang kreatif ini, melainkan masih banyak lagi karyanya yang dibuat dengan kerja keras dan sikap pantang menyerah. (Dian Miranda, 2016: 61). Kreativitas akan muncul apabila dalam pembelajaran oleh guru didukung dengan pemahaman tentang makna mengajar dan belajar. (Tanjung, Y. P, 2020: 29).

Undang-Undang Sistem Pendidikan Nasional (UU Sisdiknas) No. 20 Tahun 2003 telah menetapkan kompetensi yang harus dimiliki oleh guru. Kompetensi yang dimaksud meliputi kompetensi pedagogik, kompetensi kepribadian, kompetensi sosial, dan kompetensi profesional. Guru harus mampu membangkitkan motivasi belajar peserta didik, dan mengedepankan proses elaborasi sehingga perilaku peserta didik yang hendak diukur dapat terlihat dan muncul selama proses pembelajaran dengan mengambil prinsip belajar peserta didik aktif. (Desak Ketut Sitaasih, 2020: 242).

Kompetensi pedagogik, kompetensi kepribadian, kompetensi sosial, dan kompetensi profesional adalah empat kompetensi yang berlaku sama bagi guru di setiap jenjang pendidikan, mulai dari jenjang Pendidikan Anak Usia Dini (PAUD), jenjang Pendidikan Dasar, sampai jenjang Pendidikan Menegah Atas. Sedangkan yang membedakannya hanyalah dalam rumusan keterampilan pada setiap kompetensi saja untuk semua jenjang pendidikan.

Proses pembelajaran pada hakikatnya untuk mengembangkan aktivitas dan kreativitas siswa, melalui berbagai interaksi dan pengalaman belajar. Namun dalam pelaksanaannya masih banyak kegiatan pembelajaran yang dilaksanakan justru menghambat aktivitas dan kreativitas siswa. Hal ini dapat dilihat dalam proses pembelajaran di kelas yang pada umumnya lebih menekankan aspek kognitif, sehingga kemampuan mental yang dipelajari sebagian besar berpusat pada pemahaman bahan pengetahuan dan ingatan. 
Mengacu pada Undang-Undang Sisdiknas di atas, guru dituntut untuk memiliki skill dan menguasai seni dalam mengajar yang efektif, termasuk kreativitas dalam mengajar. Guru dituntut untuk mempunyai kemampuan dan kreativitas dalam menjalankan proses belajar mengajarnya, agar siswa dapat menerima pesan dan makna yang terkandung dalam materi bahan ajar yang disampaikan guru secara efektif dan efisien. Kemampuan kreatif individu berbeda-beda. Orang yang sangat kreatif cenderung lebih orisinal dari pada orang yang kurang kreatif.

Orang kreatif cenderung lebih luwes, dapat dan mau beralih dari satu pendekatan ke pendekatan yang lain apabila menangani suatu masalah. Orang kreatif lebih suka hal yang rumit dari pada hal yang sederhana dan cenderung mandiri dari pada orang yang kreatif. Guru memiliki kreativitas yang baik merupakan suatu keharusan. Hal yang tidak mudah untuk diraih menjadi guru yang memiliki kreativitas yang baik, perlu adanya proses pembelajaran dan kemauan yang tinggi.

Guru yang tidak menerapkan kreativitas dalam prosedur di kelas dapat membuat kreativitas akan tetap menjadi suatu konsep yang abstrak. Kreativitas itu perlu dibumikan dalam sebuah konteks pembelajaran. Guru yang memiliki ide original, karya baru, dan tepat guna dapat dimanfaatkan dalam pembelajaran. Pembelajaran merupakan aspek kegiatan manusia yang komplek, yang bermakna sebagai suatu produk interaksi berkelanjutan antara pengembangan dan pengalaman hidup.

Pembelajaran sebagai suatu konsep pedagogik secara teknis dapat diartikan sebagai upaya sistematik dan sistemik untuk menciptakan lingkungan belajar yang potensial menghasilkan proses belajar yang bermuara pada berkembangnya potensi individu sebagai siswa. (Udin S. Winataputra, 2014: $1.1)$.

\section{Guru Kreatif}

Menurut Hamzah B. Uno dan Nurdin Mohamad, profesi guru sebagai bidang pekerjaan khusus dituntut memiliki komitmen untuk meningkatkan 
pendidikan. Oleh karena itu, nilai keunggulan yang harus dimiliki guru adalah kreativitas. Kreativitas diidentifikasi dari 4 dimensi, yaitu:

a. Person

1) Mampu melihat masalah dari segala arah.

2) Hasrat ingin tahu besar.

3) Terbuka terhadap pengalaman baru;

4) Suka tugas yang menantang.

5) Wawasan luas.

6) Menghargai karya orang lain.

b. Proses

Kreativitas dalam proses dinyatakan sebagai "Creativity is a process that manifest it self in fluency, in flexibility as well as in originality of thinking". Dalam proses kreativitas ada 4 tahap, yaitu:

1) Tahap pengenalan: merasakan ada masalah dalam kegiatan yang dilakukan.

2) Tahap persiapan: mengumpulkan informasi penyebab masalah yang dirasakan dalam kegiatan itu.

3) Tahap iluminasi: saat timbulnya inspiras/gagasan pemecahan masalah.

4) Tahap verifikasi: tahap pengujian secara klinis berdasarkan realitas.

c. Product

Dimensi produk kreativitas digambarkan sebagai berikut "Creativity to bring something new into excistence" yang ditunjukkan dari sifat:

1) Baru, unik, berguna, benar, dan bernilai

2) Bersifat heuristik, menampilkan metode yang masih belum pernah/jarang dilakukan sebelumnya.

d. Press atau Dorongan

Ada beberapa faktor pendorong dan penghambat kreativitas yaitu:

1) Faktor Pendorong Kreativitas

a) Kepekaan dalam melihat lingkungan.

b) Kebebasan dalam melihat lingkungan atau bertindak.

c) Komitmen kuat untuk maju dan berhasil. 
d) Optimis dan berani ambil risiko, termasuk risiko yang paling buruk;

e) Ketekunan untuk berlatih.

f) Hadapi masalah sebagai tantangan.

g) Lingkungan yang kondusif, tidak kaku, dan otoriter.

2) Faktor Penghambat Kreativitas

a) Malas berfikir, bertindak, berusaha, dan melakukan sesuatu.

b) Implusif.

c) Anggap remeh karya orang lain.

d) Mudah putus asa, cepat bosan, tidak tahan uji.

e) Cepat puas.

f) Tak berani tanggung risiko.

g) Tidak percaya diri.

h) Tidak disiplin.

i) Tidak tahan uji. ${ }^{1}$

Menurut E. Mulyasa, kreativitas guru dapat dikembangkan sebagai berikut:

a. Menilai, menghargai berpikir kreatif.

b. Membantu anak menjadi lebih peka terhadap rangsangan dari lingkungan.

c. Memberanikan anak untuk memanipulasi benda-benda (obyek) dan ideide.

d. Mengajar bagaimana menguji setiap gagasan secara sistematis.

e. Mengembangkan rasa toleransi terhadap gagasan baru.

f. Berhati-hati dalam "memaksakan" suatu pola atau contoh tertentu.

g. Mengembangkan suatu iklim kelas yang kreatif.

h. Mengajar anak untuk menilai berpikir kreatifnya.

i. Mengajar keterampilan anak untuk menghindari atau menguasai sanksisanksi teman sebaya tanpa mengorbankan kreativitas mereka.

j. Memberikan informasi tentang proses kreativitas.

k. Menghalau perasaan kagum terhadap karya-karya besar.

${ }^{1}$ Ibid., hlm. 154-156. 
1. Memberanikan dan menilai kegiatan belajar berdasarkan inisiatif sendiri.

m. Menciptakan "duri dalam daging" membuat anak-anak menyadari adanya masalah dan kekurangan.

n. Menciptakan kondisi yang diperlukan untuk berpikir kreatif.

o. Menyediakan waktu untuk suatu keaktifan dan ketenangan.

p. Menyediakan sumber untuk menyusun gagasan-gagasan.

q. Mendorong kebiasaan untuk menyusun implikasi ide-ide.

r. Mengembangkan keterampilan untuk memberikan kritik yang membangun.

s. Mendorong kemahiran pengetahuan berbagai lapangan.

t. Menjadi guru yang hangat, bersemangat. ${ }^{2}$

Mohammad Jauhar menjelaskan guru bertindak kreatif dalam arti:

a. Mengembangkan kegiatan pembelajaran yang beragam.

b. Membuat alat bantu belajar yang berguna meskipun sederhana. ${ }^{3}$

Yatim Rianto menjelaskan bahwa guru dapat menolong siswa mengembangkan keterampilan memecahkan masalah dan sekaligus mengembangkan kreativitas melalui langkah-langkah sebagai berikut:

a. Menolong siswa mengenal masalah-masalah untuk dipecahkan.

b. Menolong siswa menemukan informasi, pengertian-pengertian, asas-asas, dan metode-metode yang perlu untuk memecahkan masalah.

c. Menolong siswa merumuskan dan membatasi masalah.

d. Menolong siswa mengalah dan kemudian menerapkan informasi, pengertian, asas-asas dan metode-metode itu pada masalah tersebut untuk memperoleh kemungkinan-kemungkinan pemecahan (hipotesis).

e. Mendorong siswa merumuskan dan menguji hipotesis-hipotesis itu untuk memperoleh pemecahan masalah.

f. Mendorong siswa mengadakan penemuan dan penilaian sendiri secara bebas. $^{4}$

${ }^{2}$ E. Mulyasa, Kurikulum Berbasis Kompetensi, (Bandung: Remaja Rosdakarya, 2006), hlm.127-128.

${ }^{3}$ Mohammad Jauhar, Op. Cit.,hlm. 163.

${ }^{4}$ Yatim Rianto,Op. Cit.,hlm. 231-232. 
Dari beberapa teori-teori di atas, penulis berkesimpulan bahwa kreativitas guru dapat dilihat melalui:

a. Person

1) Melihat masalah dari segala arah

2) Selalu ingin mengetahui hal-hal baru

3) Terbuka terhadap siswa

4) Menghargai karya siswa

b. Proses

1) Mengumpulkan informasi penyebab masalah

2) Mencari solusi untuk pemecahan masalah

3) Menyelesaikan masalah dalam pembelajaran

4) Mengembangkan kegiatan pembelajaran yang beragam

5) Membuat alat bantu belajar

6) Membantu siswa menemukan informasi terkait materi pembelajaran

c. Product

1) Menciptakan suatu karya yang baru

2) Menciptakan suatu karya yang berguna

3) Menampilkan metode pembelajaran yang jarang diterapkan

\section{KESIMPULAN}

Kreativitas guru adalah menyajikan pembelajaran dengan konsep imajinatif, melaksanakan pembelajaran yang merangsang gagasan dan karya orisinil, menyajikan pembelajaran yang bervariasi, dan menilai secara langsung dalam pembelajaran keterampilan. Kreativitas guru adalah menggunakan metode yang merangsang kreativitas siswa dan mengombinasikan beberapa metode. Metode kreatif yang digunakan oleh guru adalah metode brainstorming (curah pendapat). Metode pembelajaran yang dikombinasikan. Kreativitas guru adalah menciptakan media pembelajaran sendiri, memodifikasi media, dan mengombinasikan media. Kreativitas guru dalam pengembangan dan pemanfaatan sumber belajar adalah memanfaatkan lingkungan, memanfaatkan objek yang sering dijumpai siswa, dan memanfaatkan pengalaman siswa. 


\section{REFERENSI}

Ali. Mudlofir. (2011). Aplikasi Pengembangan Kurikulum Tingkat Satuan Pendidikan (KTSP) dan Bahan Ajar dalam Pendidikan Agama Islam. Jakarta: Rajawali Pers.

E. Mulyasa, (2006). Kurikulum Berbasis Kompetensi, Bandung: Remaja Rosdakarya.

Hamzah B. Uno dan Nurdin Mohamad, (2012). Belajar dengan Pendekatan PAIKEM, Jakarta: Bumi Aksara.

Jufni, M., Djailani, A. R., \& Ibrahim, S. (2015). Kreativitas Guru Pai Dalam Pengembangan Bahan Ajar Di Madrasah Aliyah Jeumala Amal Lueng Putu. Jurnal Administrasi Pendidikan: Program Pascasarjana Unsyiah, Volume 3, Nomor. 4, November.

Luqita, Aria. Agus Susanti. (2013). Perspektif Guru Terhadap Kemitraan Antara Sekolah, Guru Dan Masyarakat. Jurnal Psikologi Industri dan Organisasi Volume 2 Nomor. 2, Agustus.

Mamo, (2011). Pengembangan Bahan Ajar PAI Pada Sekolah. Direktorat Pendidikan Agama Islam Kementrian Agama Replublik Indonesia.

Miranda, D. (2016). Upaya Guru Dalam Mengembangkan Kreativitas Anak Usia Dini di Kota Pontianak. Jurnal Pembelajaran Prospektif, Volume 1 Nomor 1.

Mohammad Jauhar, (2011). Implementasi PAIKEM dari Behavioristik sampai Konstruktivistik, Jakarta: Prestasi Pustakaraya.

Monawati, M., \& Fauzi, F. (2018). Hubungan Kreativitas Mengajar Guru dengan Prestasi Belajar Siswa. Jurnal Pesona Dasar, Volume 6 Nomor 2 Oktober.

Pamungkas, Rahmawati, Susi Wendhaningsih, Hasyim. (2017). Peran Guru Dalam Pembelajaran Seni Tari SMAN 1 Seputih Agung Lampung Tengah. Jurnal Seni Dan Pembelajaran.

Rachmawati, Y. (2012). Strategi Pengembangan Kreativitas Pada Anak. Prenada Media.

Rahma, A. (2017). Pendidikan Humanis Paulo Freire Dalam Perspektif Pendidikan Islam (Doctoral dissertation, IAIN Raden Intan Lampung).

Sitaasih, D. K. (2020). Supervisi Akademik untuk Meningkatkan Kompetensi Guru Dalam Proses Pembelajaran di SD. Jurnal Ilmiah Sekolah Dasar, Volume 4 Nomor. 2.

Syaikhudin, Ahmad. (2013). Pengembangan Kreativitas Guru Dalam Proses Pembelajaran. LISAN AL-HAL: Jurnal Pengembangan Pemikiran dan Kebudayaan, Volume 7, Nomor. 2. 
Tanjung, Y. P. (2020). Pengaruh Kreativitas Guru Dalam Mengajar Terhadap Minat Belajar Siswa Di MTs Negeri Kota Tebing Tinggi. Murabbi, ISSN : 2620-6692 Volume 03 Nomor 01 Januari-Juni.

Winataputra, Usin S. (2014). Teori Belajar Dan Pembelajaran. MKDK 4004/Modul 1.

Yatim Rianto, (2010). Paradigma Baru Pembelajaran, (Jakarta: Kencana Prenada Media Group. 